\begin{tabular}{c|c|c}
\hline \hline Vol. 254: 307-311, 2003 & $\begin{array}{c}\text { MARINE ECOLOGY PROGRESS SERIES } \\
\text { Mar Ecol Prog Ser }\end{array}$ & Published June 4 \\
\hline
\end{tabular}

NOTE

\title{
Migration failure in stocked eels Anguilla anguilla
}

\author{
Lars Westin*
}

Ar Research Station, Gotland University College, 62035 Fårösund, Sweden

\begin{abstract}
Silver eels Anguilla anguilla L., stocked as elvers in a freshwater lake on the island of Gotland, were caught in an outlet stream leading to the Baltic Sea. After tagging, they were released either into the lake or into the stream above a fine-meshed trap, and were recaptured after a period of 3 to 120 mo. During the period between tagging and recapture, the majority lost weight and decreased in length and fat content. It is hypothesized that the stocked eels had had no opportunity to imprint the directional cues necessary for migration; i.e. they were unable to recognize the outlet stream as the starting point of migration and lacked the orientation mechanism necessary to locate the outlet to the Baltic Sea. The lake itself comprises an initial trap, and the Baltic Sea a secondary trap. It is concluded that stocked eels lack imprinting, and that consequently their contribution to recruitment is null.
\end{abstract}

KEY WORDS: European eel $\cdot$ Baltic Sea $\cdot$ Stocking $\cdot$ Imprinting $\cdot$ Maturation $\cdot$ Migration $\cdot$ Orientation

Resale or republication not permitted without written consent of the publisher

Baltic eel catches have declined precipitously since the 1940s, and there has been a long-term decrease in the recruitment of eels (Svärdson 1976, Wickström 1986). Further, there have been recent reports of a more drastic decline in the immigration of glass eels in western European countries (Hagström \& Wickström 1990, Moriarty 1990, 2000). The long-term decline seems to have been most evident in countries around the Baltic Sea, and the recent more abrupt decline has reduced an already low level of recruitment of eels to the Baltic to almost null. As a consequence, heavy stocking programmes have been undertaken in the Baltic drainage area over the past $50 \mathrm{yr}$ using eels originating from western Europe. The eel fishery in Poland, for instance, depends on stocking with imported glass eels (Moriarty et al. 1990). In Sweden also, a supplementary stocking programme has been in effect since the late 1970s (Wickström et al. 1996), and consists of transplanting elvers from the French or
English coasts. While much has been learned about stocking eels, there has been no direct evaluation of the contribution of stocked eels to Baltic catches, nor to their ultimate contribution to the spawning stock.

During the tagging procedure in an earlier study at the same locality that investigated the capacity of previously stocked silver eels to orient in the Baltic (Westin 1990), it was observed that a considerable proportion of the eels released downstream of a trap voluntarily swam back upstream. Attempts to stop these eels in the shallow stream and redirect them into the correct downstream orientation proved unsuccessful. However, the trap in which the eels had been caught lay $150 \mathrm{~m}$ upstream, and it was believed to be impossible for the eels to force their way through it in an upstream direction until 9 eels from the tagging experiment were caught a second time, 3 to 6 yr later.

Materials and methods. The eels in the present experiment orginated from the formerly eel-free lake Fardume Träsk $\left(57^{\circ} 46^{\prime} \mathrm{N}, 18^{\circ} 57^{\prime} \mathrm{E}\right)$, situated on the island of Gotland in the middle of the Baltic proper.

Lake Fardume $\left(3.4 \mathrm{~km}^{2}\right)$ is a non-stratified oligotrophic, almost mesotrophic, lake. It is very shallow, with a maximum depth of $1.5 \mathrm{~m}$ and with dense belts of reeds. The lake has a small watershed, which restricts the likelihood of eels spreading upstream. The lake was stocked in September 1980 with elvers imported from île de Ré in the Bay of Biscay, France, and a finemeshed trap (4 mm) was set up in the outlet stream, $500 \mathrm{~m}$ inland from the lake, to catch all eels leaving the lake. The migratory peak for silver eels is generally in autumn (Tesch 1983), but in this stream it occurs mainly in spring.

In spring 1991, 214 descending silver eels were trapped, anaesthetized with benzocaine, measured $(0.5 \mathrm{~cm})$, weighed (to the nearest $\mathrm{g})$, and tagged with Carlin tags, and then released directly back into the lake. 
Table 1. Anguilla anguilla. Changes in weight $(\mathrm{g})$ and length $(\mathrm{cm})$ in tagged silver eels from release to recapture. Values are means $\pm \mathrm{SE}$ of $(\mathrm{N})$ individuals

\begin{tabular}{|c|c|c|c|c|c|c|}
\hline \multirow[t]{2}{*}{ Change } & \multicolumn{5}{|c|}{ Months to recapture } & \multirow[t]{2}{*}{ Total changed } \\
\hline & $3-6$ & $\sim 12$ & $\sim 24$ & $\sim 36$ & $48-120$ & \\
\hline \multicolumn{7}{|l|}{ Weight } \\
\hline Increase & $\begin{array}{l}101 \pm 1 \\
(N=4)\end{array}$ & $\begin{array}{l}113 \pm 19 \\
(N=21)\end{array}$ & $\begin{array}{c}112 \pm 12 \\
(\mathrm{~N}=6)\end{array}$ & $\begin{array}{c}125 \pm 24 \\
(\mathrm{~N}=5)\end{array}$ & $\begin{array}{c}126 \pm 16 \\
(\mathrm{~N}=9)\end{array}$ & $\begin{array}{c}36.6 \% \\
(\mathrm{~N}=45)\end{array}$ \\
\hline Decrease & $\begin{array}{c}92 \pm 4 \\
(\mathrm{~N}=14)\end{array}$ & $\begin{array}{c}92 \pm 7 \\
(\mathrm{~N}=39)\end{array}$ & $\begin{array}{c}90 \pm 7 \\
(\mathrm{~N}=18)\end{array}$ & $\begin{array}{c}87 \pm 5 \\
(N=3)\end{array}$ & $\begin{array}{c}83 \pm 7 \\
(N=4)\end{array}$ & $\begin{array}{c}63.4 \% \\
(\mathrm{~N}=78)\end{array}$ \\
\hline \multicolumn{7}{|l|}{ Length } \\
\hline Increase & $\begin{array}{l}101 \pm 1 \\
(N=3)\end{array}$ & $\begin{array}{c}103 \pm 5 \\
(N=18)\end{array}$ & $\begin{array}{l}104 \pm 3 \\
(N=6)\end{array}$ & $\begin{array}{l}106 \pm 7 \\
(N=5)\end{array}$ & $\begin{array}{l}103 \pm 3 \\
(N=8)\end{array}$ & $\begin{array}{c}32.5 \% \\
(\mathrm{~N}=40)\end{array}$ \\
\hline Decrease & $\begin{array}{c}99 \pm 1 \\
(N=12)\end{array}$ & $\begin{array}{c}98 \pm 1 \\
(\mathrm{~N}=26)\end{array}$ & $\begin{array}{c}99 \pm 1 \\
(\mathrm{~N}=16)\end{array}$ & $\begin{array}{c}99.8 \pm 0 \\
(\mathrm{~N}=2)\end{array}$ & $\begin{array}{c}99 \pm 1 \\
(\mathrm{~N}=2)\end{array}$ & $\begin{array}{c}47.2 \% \\
(\mathrm{~N}=58)\end{array}$ \\
\hline No change & $(\mathrm{N}=3)$ & $(\mathrm{N}=16)$ & $(\mathrm{N}=2)$ & $(\mathrm{N}=1)$ & $(\mathrm{N}=3)$ & $\begin{array}{c}20.3 \% \\
(\mathrm{~N}=25)\end{array}$ \\
\hline
\end{tabular}

In a second experiment in spring 1993, 128 silver eels were trapped, tagged with Floy tags and released in the stream $75 \mathrm{~m}$ upstream of the trap.

Results. Of the 342 eels released into the lake and the stream, 114 were subsequently recaptured in addition to the 9 eels that returned voluntarily. These 123 eels were again weighed and measured to determine their growth during the release period.

Of the recaptured eels, $63.4 \%$ had lost weight, while $67.5 \%$ were either of the same length or had decreased in size. This decrease in length, however, is a question of shrinkage (Table 1).

Of the 128 tagged eels transplanted upstream in the second experiment in 1993, only $8 \%(n=10)$ migrated downstream upon release. The remainder migrated back to the lake.

Discussion. Two migratory phases were examined:

First migratory phase-leaving freshwaters: Völlestad et al. (1994) examined the environmental factors that influence the migratory behaviour of seaward-migrating wild silver European eels in the Norwegian river Imsa. These authors trapped and tagged descending silver eels and then released them $1 \mathrm{~km}$ above the trap: $79 \%$ of these were recaptured during the season in which they were released. Since some of the tagged silver eels were recaptured during migration in the following migratory season, after having spent $1 \mathrm{yr}$ in the river, Völlestad et al. (1994) assumed that if environmental conditions are unfavourable, silver eels postpone their downstream migration until the following year.

The eel stock in Lake Fardume exhibited a different pattern of behaviour. Of the 128 tagged eels transplanted upstream, only $8 \%$ migrated downstream during the season in which they were released; the remainder migrated back to the lake, and were recaptured between 3 mo and 4 yr later.
Fat content must also be considered, since it has been shown that the concentration of lipids necessary for migration and spawning must exceed $20 \%$ of the body weight (Boëtius \& Boëtius 1980).

Fat is essential for the energy-demanding migration to the Sargasso Sea, as well as for gonad development. Once it has stored sufficient lipid to meet the energetic requirements of migration and gonadal development, an eel cannot increase its fitness further by remaining in freshwater (Larsson et al. 1990). Parallel to the present tagging experiments, Svedäng \& Wickström (1997) studied the main energetic stores of the silver eel stage by analysing muscle fat concentrations in female silver eels from various habitats including marine, brackish and freshwater localities. One of these freshwater habitats was Lake Fardume. The fat content of eels from Lake Fardume was found to be surprisingly low, both in eels sampled in spring 1992 and in autumn 1993. Around $90 \%$ had a muscle fat content $<20 \%$ (mean $=13 \%$, with a wide range of 2 to $41 \% ; \mathrm{n}=60$ ). Eels with the lowest fat content came from another locality, Lake Vigdan, where $100 \%$ of the eels had a muscle fat content of $<20 \%$. It is interesting that this latter site had been stocked with elvers in 1973 and 1974, 6 to 7 yr before Lake Fardume was stocked. Svedäng \& Wickström (1997) concluded that silvering and spawning migration can occur at low muscle fat concentrations, but that it is highly unlikely that female silver eels with such a low fat content as that in Lake Fardume will recruit to the next generation. The phenomenon of silver eels not migrating out of the Baltic Sea has previously been attributed to loss of migratory orientation (Westin 1990, 1998), but Svedäng \& Wickström (1997) proposed that failure to orient could alternatively be explained by such eels prolonging their initial migratory phase in order to 
feed and build up the body energy reserves needed for their long reproductive migration. Many questions remain: Why, in contrast to wild eels (Völlestad et al. 1994), did $92 \%$ of the stocked eels in Lake Fardume interrupt their seaward migration and voluntarily return to the lake? Why did they return to the stream and trap a second time 3 to 120 mo later? Why did this also occur when eels were released directly into the lake? What causes the observed decrease in body fat and weight in eels migrating downstream from the lake? Finally, what benefit do the eels gain by prolonging the migratory phase to include a new feeding period (this time in the Baltic) before leaving European waters (Svedäng \& Wickström 1997)?

There is another possible explanation for the behaviour of eels in the Baltic (Westin 1990, 1998): that they do not migrate at all. As these eels begin to mature they develop a migratory instinct, accompanied by high motoric activity (Westin \& Nyman 1979), but are unable to channel this correctly. Since they have had no opportunity to imprint the starting point (outlet stream) of their spawning migration, they merely respond to an unknown migratory cue by increased activity. The occurrence of eels in the outlet stream is accidental and coupled to periods of high waterflow that occur predominantly in spring. Their increased activity would explain why the eels from Lake Fardume are mainly caught in spring, in contrast to wild eels which migrate in autumn at these latitudes (Tesch 1983, Völlestad et al. 1994).

Difficulties of stocked eels in finding their way out of a lake has also been reported for Lake Götemaren in SE Sweden, which was stocked with elvers from the same locality in France as Lake Fardume, also in 1980. A remarkably high percentage of silver eels, mostly males, were caught in fyke-nets and not in the outlet trap in 1991 and 1994, indicating that they had some difficulty in finding the outlet of the lake (Wickström et al. 1996).

Eels are assumed to stop feeding at the silver eel stage (Pankhurst \& Sorensen 1984), and would therefore be expected to deplete their energy reserves. However, trapped silver eels from Lake Fardume often had full stomachs, indicating that at the time of capture they were actively feeding rather than migrating. It has recently been shown that silver eels can revert to yellow eel characteristics (Feunteun et al. 2000).

The wide range in lipid content (2 to $41 \%$ ) recorded in eels from Lake Fardume may reflect variation in the time elapsed between maturation and capture. Maturation is normally followed by migration. If migration is halted for any reason, the eel can cope with this to a certain point, after which it begins losing fat and thus weight, followed by death.
Thus, a new question arises: How long can an eel survive after maturation? After $20 \mathrm{yr}$, female silver eels in seemingly good condition are still being caught in the trap.

The fate of males in Lake Fardume may partly answer this question. Males are seldom found in this part of the Baltic drainage area but, as a result of the stocking in Lake Fardume, silver eel males totally dominated all catches during the first $3 \mathrm{yr}$ of the silver eel run (Wickström et al. 1996). This is due to the fact that in the European eel, males mature earlier and at a smaller size than females. One male recaptured after 5 yr (12 yr after stocking) had lost $27 \%$ in weight. The last males, however, were caught 16 yr after stocking and were peculiar in appearance, being lean with unusually enlarged eyes and with the ventral side of the body reddish-brown or copper in colour. In addition, the pectoral fins were almost black and very pointed and lengthened. Such eels, so-called 'macrophthalmous' eels, have also been reported earlier from the Baltic Sea (Svärdson 1949). No such specimens have been observed under natural conditions for the American eel Anguilla rostrata, but have been reported from a land-locked lake in Michigan, Canada, for $A$. rostrata that orginated from elvers liberated into the lake (Vladykov 1973). Lake Fardume may function in much the same way as a land-locked lake for the A. rostrata stock.

Second migratory phase-through the Baltic Sea: An ongoing debate about stocked eels in the Baltic is whether or not they can locate the way out in order to spawn (Westin 1990,1998, Tesch et al. 1991). In successive tagging studies, stocked eels have taken months to years longer to reach the southern Baltic than control groups of wild eels, and indeed could still be caught there up to $4 \mathrm{yr}$ after release. They also failed to locate the exit from the Baltic at Öresund and instead were recaptured in the southern Baltic and along the coasts of Poland, Germany and Denmark, extremely unusual localities for migrating wild eels. It has also been shown that wild eels rendered anosmic by plugging their nostrils had poorer navigation abilities. Therefore, stocked eels, which have never been in the Baltic before and thus lack the olfactory imprints of its salinity gradients, cannot orient in the Baltic (Westin 1990, 1998).

Limburg et al. (2003) analysed a matrix of data on maturity status and lipid content in silver eels. In addition, they used electron (walleye dermal sarcoma) and nuclear (microPIXE) microprobes to determine the strontium and calcium contents of their otoliths. $\mathrm{Sr}: \mathrm{Ca}$ correlates with salinity and thus allows the environmental history of migrating Baltic eels to be traced. For the purpose of calibration, Limburg et al. (2003) analysed otoliths from eels collected around the 
Swedish coast and from freshwaters. Eels that were experimentally stocked and monitored in Lake Fardume and Lake Ången served as known freshwater end-members. Silver eels were also collected at sites exiting or outside the Baltic Sea as well as in the southern Baltic in the vicinity of the Danish islands of Lolland and Falster, where many previously stocked eels from Lake Fardume have been found (Westin 1990, 1998).

Collectively, the $\mathrm{Sr}$ :Ca content of silver eels revealed a wide repertoire of habitat use that differed between eels caught exiting or outside the Baltic Sea, and those collected in the Baltic around the Danish islands of Lolland and Falster. Within the 7 groups of brackish and/or freshwater origin collected in Danish Baltic waters, the wild catadromous eels had the highest lipid content. The lowest lipid content was found in previously stocked eels that had spent their entire lives in freshwater, and these eels were almost exclusively found in the Danish islands sample (Limburg et al. 2003).

Recently, van Ginneken \& van den Thillart (2000) reported that the energetic cost of swimming for eels is $0.137 \mathrm{cal} \mathrm{g}^{-1}$ wet weight $\mathrm{km}^{-1}$. Based on data in their paper it is possible to compute a migration potential. Results of such calculations for samples from Lolland and Falster indicate that catadromous eels had the highest migration potential, and stocked eels that spent their entire lives in freshwater the lowest, and that on the whole, the latter lacked sufficient energy reserves for the journey to the Sargasso Sea (Limburg et al. 2003). This is in accordance with a finding that stocked individuals did not orient properly and missed the exit from the Baltic at Öresund (Westin 1990, 1998). The stocked mature silver eels from Lake Fardume may have no useful future. They are trapped in the lake in which they were stocked, and should they accidentally find their way out into the Baltic Sea, then they would be trapped there also.

The eel is of great commercial value throughout Europe, with a turnover of about $€ 180$ million $\mathrm{yr}^{-1}$ (Feunteun et al. 2000). Stocking Lake Fardume was a good short-term investment (Wickström et al. 1996), but brings no long-term benefit to the natural eel population, since it makes no contribution to natural recruitment.

The conclusions to be drawn from investigations on stocked eels in Lake Fardume (Westin 1990, 1998, Wickström et al. 1996, Svedäng \& Wickström 1997, Limburg et al. 2003) are that cue imprintment seems to be essential for eel orientation; lack of it results in no spawning. In short, the stocked eels under study lack imprinting, and thus their contribution to future generations is null.
The European eel is generally cosidered a panmictic species. However, recent new genetic evidence against panmixia in the European eel has been presented by Wirth \& Bernatchez (2001) that suggests that genetically distinct sub-groups may exist. The genetic pattern implies non-random mating and resricted gene flow among eels from different locations along the European coastline (northern, western and southern regions of Europe).

Over the past $50 \mathrm{yr}$, the Baltic Sea region has been heavily stocked with elvers transplanted from western Europe (France and England). My results indicate that the transplanted individuals do not participate in spawning, and thus that the transplantations will not have affected the natural genetic structure of the European eel population.

Acknowledgements. The author gratefully acknowledges the support given by the Carl Tryggers Fund, Gunvor and Josef Anérs Fund and the World Wide Fund for Nature.

\section{LITERATURE CITED}

Boëtius I, Boëtius J (1980) Experimental maturation of female silver eels, Anguilla anguilla (L.): estimates of fecundity and energy reserves for migration and spawning. Dana 4: $1-17$

Feunteun E, Acou A, Laffaille P, Legault A (2000) European eel (Anguilla anguilla): prediction of spawner escapement from continental population parameters. Can J Fish Aquat Sci 57:1627-1635

Hagström O, Wickström H (1990) Immigration of young eels to the Skagerrak-Kattegat area 1900-1989. Int Rev Ges Hydrobiol 75:11-20

Larsson P, Hamrin S, Okla L (1990) Factors determining the uptake of persistent pollutants in an eel population (Anguilla anguilla L.). Environ Pollut 69:39-50

Limburg KE, Wickström H, Svedäng H, Elfman M, Kristiansson P (2003) Do stocked freshwater eels migrate? Evidence from the Baltic suggests 'yes'. In: Dixon DA (ed) Biology, management and protection of catadromous eels. American Fisheries Society (in press)

Moriarty C (1990) European catches of elver of 1928-1988. Int Rev Ges Hydrobiol 75:701-706

Moriarty C (2000) Monitoring results for glass eel and elver 1965-1999. Dana 12:69-70

Moriarty C, Bninska M, Leopold M (1990) Eel, Anguilla anguilla L., stock and yield in Polish lakes. Aquacult Fish Manag 21:347-355

Pankhurst NW, Sorensen PW (1984) Degeneration of the alimentary tract in sexually maturing European Anguilla anguilla (L.) and American eels Anguilla rostrata (LeSueur). Can J Zool 62:1143-1149

Svärdson G (1949) Eels (Anguilla anguilla) found in Sweden in partial nuptial dress. Rep Inst Freshw Res Drottningholm 29:129-134

Svärdson G (1976) The decline of the Baltic eel population. Rep Inst Freshw Res 55:136-143

Svedäng H, Wickström H (1997) Low fat contents in female 
silver eels: indications of insufficiant energetic stores for migration and gonadal development. J Fish Biol 50: $475-486$

Tesch FW (1983) Der Aal: Biologie und Fischerei. Paul Parey, Hamburg

Tesch FW, Westerberg H, Karlsson L (1991) Tracking studies on migrating silver eels in the Central Baltic. Meeresforschung 33:183-196

van Ginneken V, van den Thillart G (2000) Eel fat stores are enough to reach the Sargasso. Nature 403:156-157

Vladykov VDJ (1973) Macrophthalmia in the American eel (Anguilla rostrata). J Fish Res Board Can 30:689-693

Völlestad LA, Jonsson B, Hvidsten NA, Naesje TF (1994) Experimental test of environmental factors influencing the seaward migration of European silver eels. J Fish Biol 45:641-651

Editorial responsibility: Otto Kinne (Editor),

Oldendorf/Luhe, Germany
Westin L (1990) Orientation mechanisms in migrating European silver eel (Anguilla anguilla): temperature and olfaction. Mar Biol 106:175-179

Westin L (1998) The spawning migration of European silver eel (Anguilla anguilla L.) with particular reference to stocked eel in the Baltic. Fish Res 38:257-270

Westin L, Nyman L (1979) Activity, orientation and migration of Baltic eel (Anguilla anguilla L.). Rapp P-V Réun Cons Perm Int Explor Mer 174:115-123

Wickström H (1986) Growth of cultured eels stocked in two Swedish lakes. Vie Milieu 36:273-277

Wickström H, Westin L, Clevestam P (1996) The biological and economic yield from a long-term eel-stocking experiment. Ecol Freshw Fish 5:140-147

Wirth T, Bernatche L (2001) Genetic evidence against panmixia in the European eel. Nature 409:1037-1039

Submitted: October 11, 2002; Accepted: February 18, 2003

Proofs received from author(s): May 19, 2003 